\title{
Functional role of intrahepatic monocyte subsets for the progression of liver inflammation and liver fibrosis in vivo
}

Frank Tacke

From Fibroproliferative disorders: from biochemical analysis to targeted therapies

Frauenchiemsee, Germany. 25-30 September 2010

\begin{abstract}
Sustained inflammation upon chronic liver injury induces the development of liver fibrosis in mice and men. Experimental models of liver fibrosis highlight the importance of hepatic macrophages, so-called Kupffer cells, for perpetuating inflammation by releasing proinflammatory cytokines and chemokines as well as activating hepatic stellate cells (HSC). Recent studies in mice demonstrate that these actions are only partially conducted by liverresident macrophages, classically termed Kupffer cells, but largely depend on recruitment of monocytes into the liver. Monocytes are circulating precursors of tissue macrophages and dendritic cells (DC), which comprise two major subsets in blood, characterized by the differential expression of chemokine receptors, adhesion molecules and distinct markers, such as Ly6C/Gr1 in mice or CD14 and CD16 in humans. Upon organ injury, chemokine receptor CCR2 and its ligand MCP-1 (CCL2) as well as CCR8 and CCL1 promote monocyte subset accumulation in the liver, namely of the inflammatory $\mathrm{Ly}_{6} \mathrm{C}^{+}\left(\mathrm{Gr}^{+}\right)$monocyte subset as precursors of tissue macrophages. The infiltration of proinflammatory monocytes into injured murine liver can be specifically blocked by novel anti-MCP-1 directed agents. In contrast, chemokine receptor CX3CR1 and its ligand fractalkine (CX3CL1) are important negative regulators of monocyte infiltration in hepatic inflammation by controlling their survival and differentiation into functionally diverse macrophage subsets. In patients with liver cirrhosis, 'non-classical' CD $14^{+} \mathrm{CD} 16^{+}$monocytes are found activated in blood as well as liver and promote pro-inflammatory along with pro-fibrogenic actions by the release of distinct cytokines and direct interactions with HSC, indicating that the findings from murine models can be translated into pathogenesis of human liver fibrosis. Moreover, experimental animal models indicate that monocytes/macrophages and DCs are not only critical for fibrosis progression, but also for fibrosis regression, because macrophages can also degrade extracellular matrix proteins and exert anti-inflammatory actions. The recently identified cellular and molecular pathways for monocyte subset recruitment, macrophage differentiation and interactions with other hepatic cell types in injured liver may therefore represent interesting novel targets for future therapeutic approaches in liver fibrosis.
\end{abstract}

\section{Introduction}

Chronic liver inflammation is a major health problem worldwide, eventually resulting in liver fibrosis, end-stage liver cirrhosis, organ failure, hepatocellular carcinoma and ultimately death. In industrialized countries, chronic hepatitis $\mathrm{C}$, alcohol abuse and non-alcoholic steatohepatitis (NASH) are major causes for liver cirrhosis [1]. Liver

Correspondence: frank.tacke@gmx.net

Dept of Medicine III, University Hospital Aachen, Germany fibrosis commonly develops as a result of chronic organ inflammation which is characterized by the infiltration and activation of immune cells, leading to both inflammatory as well as wound healing responses including subsequent necrosis and apoptosis of parenchymal cells and replacement by connective tissue and extracellular matrix (ECM) proteins. Although the different etiologies of liver fibrosis (e.g., alcohol abuse, chronic viral hepatitis, metabolic syndrome and autoimmune disorders) employ different mechanisms of hepatocyte injury, the resulting
C Biomed Central

(c) 2012 Tacke; licensee BioMed Central Ltd. This is an Open Access article distributed under the terms of the Creative Commons Attribution License (http://creativecommons.org/licenses/by/2.0), which permits unrestricted use, distribution, and reproduction in any medium, provided the original work is properly cited. 
steps promoting fibrosis development have been found to be astonishingly similar despite the very different disease onsets [2].

Over recent years, several studies have emphasized the crucial role of infiltrating monocytes for the progression of liver inflammation and fibrosis in experimental mouse models [3-7]. It has become clear that the macrophage compartment of the liver, traditionally called 'Kupffer cells', is constantly replenished to a significant extent by blood monocytes $[1,8]$ and is greatly augmented by an overwhelming number of infiltrating monocytes upon acute or chronic liver injury [4,9]. During fibrosis progression in mice, monocyte-derived macrophages can release several cytokines perpetuating chronic inflammation as well as directly activate hepatic stellate cells (HSC), resulting in their proliferation and transdifferentiation into collagen-producing myofibroblasts $[3,4,7]$. Nevertheless, it has to be kept in mind that liver-resident macrophages (Kupffer cells) may be capable of proliferating under certain conditions [10]. However, up to now this Kupffer cell proliferation has only be observed in inflammatory conditions that are extremely skewed towards "type 2" responses (T-helper cell 2/interleukin-4 driven conditions), such as parasitic infections [10], raising the question whether local macrophage proliferation could be of general relevance in liver fibrosis as well [11]. This review will discuss recent evidence from our laboratory about the functional role of monocyte subsets for liver inflammation and fibrosis as well as distinct chemokine actions driving monocyte migration and differentiation that may possibly represent novel therapeutic targets in hepatic fibrosis.

\section{Monocyte subsets in men and mice}

Monocytes represent about 5-10\% of peripheral blood leukocytes in humans and mice. They originate from a myeloid precursor in the bone marrow, circulate in the blood, bone marrow and spleen, and then enter tissues $[12,13]$. Monocytes are regarded as circulating precursors for tissue macrophages and dendritic cells (DCs). Migration of monocytes into tissues and differentiation into macrophages or DCs is believed to be largely determined by the inflammatory milieu, i.e. adhesion molecules, chemokines and pathogen-associated pattern-recognition receptors [12].

Heterogeneity among human monocytes was recognized over twenty years ago [14]. The differential expression of CD14 (part of the receptor for lipopolysaccharide) and CD16 (also known as FcyRIII) were used to define two major subsets in peripheral blood: 'classical' CD14 ${ }^{+}$ ${ }^{+} \mathrm{CD} 16^{-}$monocytes, typically representing up to $95 \%$ of the monocytes in healthy individuals, and the "non-classical' $\mathrm{CD} 14^{+} \mathrm{CD} 16^{+}$cells comprising the remaining fraction of monocytes [15]. These subsets differ in many respects, including adhesion molecule and chemokine receptor (CCR) expression. CD14 ${ }^{++} \mathrm{CD} 16^{-}$monocytes express CCR2, CD62L (L-Selectin) and Fc $\gamma$ RI (CD64), whereas $\mathrm{CD} 14^{+} \mathrm{CD} 16^{+}$monocytes lack CCR2, and have higher levels of MHC-II and FC $\gamma$ RII (CD32). Both subsets express the receptor for fractalkine, $\mathrm{CX}_{3} \mathrm{CR} 1$, but $\mathrm{CD} 14^{+} \mathrm{CD} 16^{+}$monocytes characteristically express higher levels $[13,16]$.

More recently, it was noted that different monocyte subpopulations also exist in mice [17]. Based on similar adhesion molecule and chemokine receptor as well as similar gene expression profiles, murine $\mathrm{Ly} 6 \mathrm{C}^{\text {hi }}\left(\mathrm{Gr} 1^{\text {hi }}\right)$ monocytes are considered counterparts of human CD14 ${ }^{++} \mathrm{CD} 16^{-}$monocytes, and murine $\mathrm{Ly} 6 \mathrm{C}^{\mathrm{lo}}\left(\mathrm{Gr} 1^{\mathrm{lo}}\right)$ may represent the subpopulation comparable to human CD16 ${ }^{+}$monocytes [16]. More recently, human CD16 ${ }^{+}$ monocytes have been further subdivided into 'intermediate' $\mathrm{CD} 14^{+} \mathrm{CD} 16^{+}$and 'non-classical' $\mathrm{CD} 14^{\mathrm{dim}} \mathrm{CD} 16^{++}$ cells [18], with the latter likely sharing important functional similarities to murine Ly6 $\mathrm{C}^{\mathrm{lo}}$ monocytes [19].

\section{Migratory and functional differences of monocyte subsets}

Based on a distinct pattern of chemokine receptors expressed on their surface, both monocyte subsets show fundamentally different patterns in their migratory behavior. Namely, the chemokine receptors CCR1 and CCR2 are more highly expressed on Ly6 $\mathrm{C}^{\text {hi }}$ mouse monocytes, whereas CCR 5 and $\mathrm{CX}_{3} \mathrm{CR} 1$ are elevated on murine Ly6 $C^{\text {lo }}$ monocytes $[13,16,20]$. Both subsets constitutively patrol the blood vessels of the entire circulation and also to some extent the secondary lymphatic system. Monocytes therefore are able to act as 'first responders' to inflammatory signals, infiltrating inflamed tissues shortly after the onset of injury. This process has mainly been observed for Ly6 $\mathrm{C}^{\mathrm{hi}}$ monocytes and is highly dependent on chemokine receptors CCR2 and CCR6 [21-23]. CCR2 has been described to mediate release of Ly $6 \mathrm{C}^{\text {hi }}$ monocytes from the bone marrow as well as driving tissue infiltration directly [20,24-26], whereas CCR6 (ligand: CCL20) seems to be of some importance for guiding infiltrating cells to the site of injury once the monocytes have left the bloodstream e.g. in inflamed skin areas $[23,27,28]$. In injured liver, the chemokine receptor CCR8 appears to be also critical for $\mathrm{Ly} 6 \mathrm{C}^{\mathrm{hi}}$ monocyte accumulation and subsequent pro-inflammatory macrophage differentiation in vivo [29]. Ly6C $\mathrm{C}^{\mathrm{hi}}$ monocytes are rapidly recruited to sites of inflammation, such as in atherosclerosis, peritonitis, urinary tract infection or after organ damage into the injured liver $[4,20,24,30,31]$. Within the inflamed tissue, Ly6 $\mathrm{C}^{\text {hi }}$ monocytes were found to give rise to pro-inflammatory macrophages and TNF-producing DCs in inflamed tissue $[4,12,20,26,31]$. 
In contrast, $\mathrm{Ly} 6 \mathrm{C}^{\mathrm{lo}}$ monocytes appear to have a more patrolling behavior at the endothelium [32]. Imaging studies using intravital microscopy in dermis tissue suggested that Ly6C $C^{\text {lo }}$ cells scarcely leave blood vessels without inflammatory stimuli, but rather showed a patrolling behaviour rolling along endothelia in a LFA-1 and $\mathrm{CX}_{3} \mathrm{CR} 1$ dependent fashion [17]. Ly6 $\mathrm{C}^{\mathrm{lo}}$ monocytes have also been found to migrate into the inflamed intima in atherosclerotic plaques where they preferentially differentiate into 'non-classical' CD11 ${ }^{+}$macrophages [20]. Other studies indicated that $\mathrm{Ly} 6 \mathrm{C}^{\mathrm{lo}}$ monocytes may serve as precursors for alternatively activated macrophages, possibly fulfilling functions in tissue repair and resident macrophage/DC turnover $[12,32,33]$. A natural reservoir for Ly6 $\mathrm{C}^{\mathrm{lo}}$ monocytes in vivo appears to be the spleen [34].

The origin of 'non-classical' Ly6C ${ }^{\text {lo }}$ monocytes is controversially debated among monocyte researchers. It is apparent that Ly6 $\mathrm{C}^{\mathrm{lo}}$ monocytes can develop from Ly6C $\mathrm{C}^{\text {hi }}$ monocytes as a more mature subset $[35,36]$, and the 'conversion' from Ly6C $C^{\text {hi }}$ to Ly $6 C^{\text {lo }}$ monocytes likely takes place in the bone marrow under homeostatic conditions [36]. However, experimental data exist indicating that Ly $6 \mathrm{C}^{\mathrm{lo}}$ monocytes may also in parallel arise from distinct precursors in the bone marrow, independent from the Ly6C ${ }^{\text {hi }}$ subset [12,30,37]. From experimental hepatological research, very limited data exist about the functional role of Ly6 $\mathrm{C}^{\mathrm{lo}}$ monocytes, but it has to be mentioned that infiltrating, inflammatory Ly6 $\mathrm{C}^{\text {hi }}$ monocytes rapidly downregulate Ly6C surface expression upon transmigration into (injured) liver $[4,38]$.

\section{Role of CCR2 and CCR8 for monocyte infiltration in liver fibrosis}

Accumulating evidence from murine models demonstrated that the infiltration of monocytes into the liver is a major pathogenic factor for chronic hepatic inflammation and fibrosis [3-6]. In order to identify the role of monocyte subsets in hepatic fibrosis, we characterized subpopulations of infiltrating monocytes in acute and chronic carbon tetrachloride $\left(\mathrm{CCl}_{4}\right)$-induced liver injury in mice using flow-cytometry and immunohistochemistry [4]. Inflammatory Ly $6 C^{\text {hi }}$, but not Ly6 $C^{\text {lo }}$ monocytes were massively recruited into the liver upon toxic injury constituting an up to 10 -fold increase in $\mathrm{CD} 11 \mathrm{~b}^{+} \mathrm{F} 4 / 80^{+}$intrahepatic macrophages early (24-48 hours) after $\mathrm{CCl}_{4}$ injection and persistently a 3 - to 5 -fold increase in fibrotic livers at 6 weeks after biweekly $\mathrm{CCl}_{4}$ injections. During chronic liver damage, intrahepatic $\mathrm{CD} 11 \mathrm{~b}^{+} \mathrm{F} 4 / 80^{+} \mathrm{Ly} 6 \mathrm{C}^{+}$monocytederived cells differentiated preferentially into iNOS-producing macrophages exerting proinflammatory and profibrogenic actions, e.g. promoting hepatic stellate cell (HSC) activation, $\mathrm{T}_{\mathrm{H}} 1-\mathrm{T}$ cell differentiation and transforming growth factor beta (TGF $\beta$ )-release [4].
Because Ly6C ${ }^{\text {hi }}$ monocytes express high levels of CCR2 [20] and activated hepatic stellate cells were shown to release high amounts of the CCR2-ligand MCP-1 $[39,40]$, we compared wildtype with CCR2- and CCR2/CCR6-deficient mice in the $\mathrm{CCl}_{4}$ fibrosis model in order to identify possible chemokine receptor pathways mediating monocyte migration into the liver. These experiments revealed that the chemokine receptor CCR2 critically controls intrahepatic Ly6 $\mathrm{C}^{\text {hi }}$ monocyte accumulation, at the level of mediating their egress from the bone marrow. Impaired monocyte subset recruitment in CCR $2^{-/-}$and CCR2 $2^{-/-}$ $\mathrm{CCR}^{-1-}$ mice resulted in reduced $\mathrm{HSC}$ activation and diminished liver fibrosis. Moreover, adoptively transferred Ly $6 \mathrm{C}^{\mathrm{hi}}$ monocytes traffic into the injured liver and promote fibrosis progression in wildtype and CCR2 $2^{-1-} \mathrm{CCR}^{-1-}$ mice, which are otherwise protected from hepatic fibrosis. Intrahepatic $\mathrm{CD} 11 \mathrm{~b}^{+} \mathrm{F} 4 / 80^{+} \mathrm{Ly}_{6 \mathrm{C}^{+}}$monocyte-derived macrophages purified from $\mathrm{CCl}_{4}$-treated animals, but not 'naïve' bone marrow monocytes or control lymphocytes, directly activate HSC in a TGF $\beta$-dependent manner in vitro [4]. Collectively, these data indicate that inflammatory Ly $6 \mathrm{C}^{+}$monocytes, recruited into the injured liver via CCR2-dependent bone marrow egress, promote the progression of liver fibrosis (Figure 1).

Several independent studies highlighted the importance of the chemokine receptor CCR2 and its cognate ligand monocyte-chemoattractant protein 1 (MCP-1/CCL2) for monocyte recruitment during experimental hepatic fibrosis [3-6], suggesting that inhibition of CCR2 or MCP-1 might bear therapeutic potential in hepatic fibrosis. Therefore, we have investigated the pharmacological inhibition of MCP-1 via the structured L-enantiomeric RNA oligonucleotide mNOX-E36 (a so-called Spiegelmer) that potently binds and inhibits murine MCP- 1 in two murine models of chronic liver diseases [41]. Antagonizing MCP1 by mNOX-E36 efficiently inhibited murine monocyte chemotaxis in vitro as well as migration of Ly6C $\mathrm{C}^{+}$blood monocytes into liver upon injury in vivo. In line with lower levels of intrahepatic macrophages, pro-inflammatory cytokines (TNF, IFN $\gamma$, IL-6) were significantly reduced in injured liver tissue, and the development of steatosis and steatohepatitis was ameliorated by antiMCP-1 treatment [41].

Moreover, CCR1 and CCR5, receptors for the chemokines CCL3/MIP1 $\alpha$, CCL4/MIP1 $\beta$ and CCL5/ RANTES, were found to promote liver fibrosis in mice [9]. Of note, while the function of CCR 1 could be attributed to infiltrating immune cells (most likely Ly6 $\mathrm{C}^{+}$monocytes), CCR5 appears to exert its actions primarily on resident hepatic non-parenchymal cells, most probable on HSC [9]. Recent experimental data from our laboratory indicate that the chemokine receptor CCR8 (main ligand: CCL1) is also involved in 


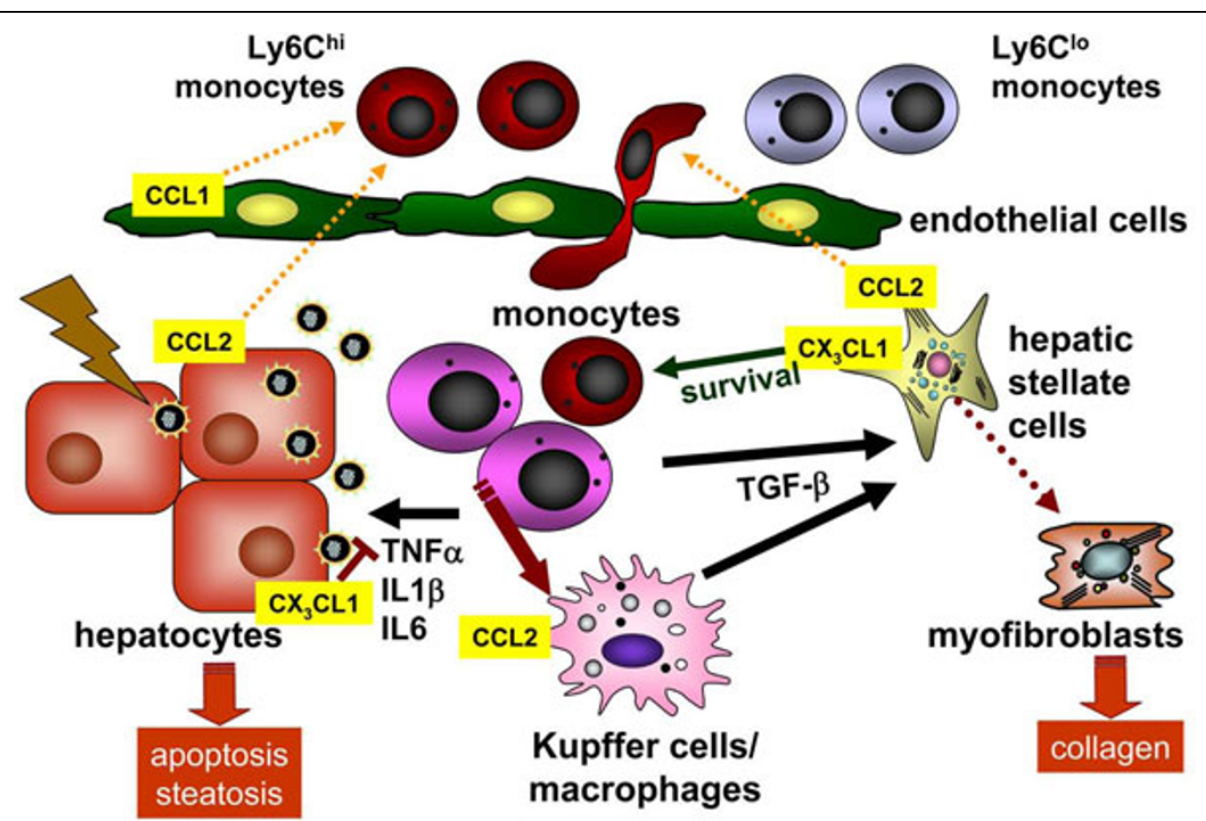

Figure 1 Monocyte subsets in experimental liver fibrosis in mice. Upon liver injury, hepatocytes, hepatic stellate cells, endothelium and resident macrophages (Kupffer cells) release many cytokines and chemokines (not shown in detail). CCL2 is an important mediator that promotes the accumulation of inflammatory CCR2 ${ }^{+}$Ly6C $C^{\text {hi }}\left(\mathrm{Gr}^{\text {hi }}\right)$ monocytes from blood into the injured liver. CCR8 and its ligand CCL1 also promote monocyte/macrophage migration in hepatic fibrosis. Intrahepatic monocytes develop preferentially into 'M1' inflammatory macrophages in this setting. These monocytes/macrophages release proinflammatory cytokines such as TNF $\alpha$, IL $1 \beta$ or IL6 that further promote hepatocyte apoptosis, hepatocyte steatosis and inflammation, but also directly interact with hepatic stellate cells via TGF $\beta$, thereby contributing to myofibroblast transdifferentiation and collagen production. $\mathrm{CX}_{3} \mathrm{CL} 1-\mathrm{CX}{ }_{3} \mathrm{CR} 1$ interactions on monocytes/macrophages are anti-inflammatory and anti-fibrotic by prolonging monocyte survival and limiting $\mathrm{M} 1$ macrophage differentiation.

directing infiltration of inflammatory monocytes into injured liver and in promoting preferential differentiation into macrophages with a pro-inflammatory phenotype [29]. CCR8-deficient mice showed significantly reduced hepatic fibrosis in two independent experimental models, which was accompanied by reduced intrahepatic monocytes/macrophages and could be restored by adoptively transferring CCR8-expressing Ly6 $\mathrm{C}^{\text {hi }}$ bone marrow monocytes [29].

\section{Role of $\mathrm{CX}_{3} \mathrm{CR} 1$ for macrophage differentiation in liver fibrosis}

The chemokine receptor $\mathrm{CX}_{3} \mathrm{CR} 1$ is expressed at high levels on both monocyte subsets $\left(\mathrm{Ly} 6 \mathrm{C}^{\mathrm{lo}}>>\mathrm{Ly} 6 \mathrm{C}^{\mathrm{hi}}\right.$ ) and has been identified as an important regulator of monocyte migration, differentiation and survival [13]. Preliminary observations have linked $\mathrm{CX}_{3} \mathrm{CR} 1$ and its ligand fractalkine $\left(\mathrm{CX}_{3} \mathrm{CL} 1\right)$ to the pathogenesis of chronic liver diseases. As such, fractalkine and $\mathrm{CX}_{3} \mathrm{CR} 1$ were found up-regulated in biopsies of patients with acute and chronic liver injury [42], especially in cholestatic diseases [43,44]. Furthermore, $\mathrm{CX}_{3} \mathrm{CR} 1$ gene polymorphisms have been associated with fibrosis progression in patients with chronic hepatitis C [45]. Experimentally, shedding of $\mathrm{CX}_{3} \mathrm{CL} 1$ by HSC promoted chemoattraction of monocytes in vitro [46], and the adhesion of human $\mathrm{CD}_{16}{ }^{+}$monocytes to liver sinusoidal endothelium was partially mediated by $\mathrm{CX}_{3} \mathrm{CR} 1$ [47]. We therefore set out experiments to define the role of fractalkine and $\mathrm{CX}_{3} \mathrm{CR} 1$ for liver inflammation and fibrosis.

To analyze the functional relevance of this pathway, two models of experimental liver fibrosis were applied to wildtype (WT) and $\mathrm{CX}_{3} \mathrm{CR} 1$-deficient mice, namely repetitive carbon tetrachloride $\left(\mathrm{CCl}_{4}\right)$ injections as well as surgical ligation of the biliary duct (BDL, bile duct ligation) [48]. Upon liver injury in mice, fractalkine expression was induced, primarily in hepatocytes and hepatic stellate cells (HSC). $\mathrm{CX}_{3} \mathrm{CR}^{-/-}$developed greater hepatic fibrosis than WT animals in $\mathrm{CCl}_{4}$ - and BDL-induced fibrosis. Surprisingly, $\mathrm{CX}_{3} \mathrm{CR}^{-1-}$ mice displayed significantly increased numbers of monocyte-derived macrophages within the injured liver. Bone marrow transplanted chimeric animals revealed that $\mathrm{CX}_{3} \mathrm{CR} 1$ restricts hepatic fibrosis progression and monocyte accumulation through mechanisms exerted by infiltrating immune cells. In the absence of $\mathrm{CX}_{3} \mathrm{CR} 1$, intrahepatic monocytes developed preferentially into proinflammatory TNF- and iNOS-producing macrophages (Figure 1) [48]. This impact on differentiation has been also observed by in-vitro experiments, which demonstrated increased TNF and reduced arginase-1 expression 
by $\mathrm{CX}_{3} \mathrm{CR} 1$-deficient hepatic macrophages upon $\mathrm{CCl}_{4}$ stimulation [49].

Although $\mathrm{CX}_{3} \mathrm{CL} 1$ was originally defined as a chemoattractant for monocytes $[20,50]$ a growing body of evidence indicated that $\mathrm{CX}_{3} \mathrm{CR} 1$ is involved in controlling cell survival. In conditions of hepatic inflammation and fibrosis, $\mathrm{CX}_{3} \mathrm{CR} 1$ represents an essential survival signal for hepatic monocyte-derived macrophages by activating anti-apoptotic $b c l-2$ expression [48]. Monocytes/macrophages lacking $\mathrm{CX}_{3} \mathrm{CR} 1 \mathrm{undergo}$ increased cell death following liver injury, which then perpetuates inflammation, promotes prolonged inflammatory monocyte infiltration into the liver and results in enhanced liver fibrosis [48]. Taken together, $\mathrm{CX}_{3} \mathrm{CR} 1$ limits liver fibrosis in vivo by controlling differentiation and survival of intrahepatic monocytes (Figure 1). Pharmacological augmentation of this pathway may thus represent a possible therapeutic antifibrotic strategy [51].

\section{Role of monocyte subsets for fibrosis regression}

Although infiltrating monocytes/macrophages have clearly been shown to contribute to the progression of fibrosis in vivo (see above), they appear to be capable of acting as important beneficial contributors to fibrosis regression as well [51]. The selective depletion of macrophages, using a transgenic mouse model with diphtheria toxin receptor expression on myeloid $\left(\mathrm{CD}_{11} \mathrm{~b}^{+}\right)$cells, during the resolution phase after $\mathrm{CCl}_{4}$-induced injury significantly impaired resolution of fibrosis [7]. This effect could be mainly attributed to reduced expression of matrix metalloproteinase (MMP) 13 (collagenase 3) by scar-associated macrophages, which is the key enzyme to degrade excessive extracellular matrix proteins [52]. Moreover, macrophage derived elastase MMP-12 regulates the degradation of elastin, which is a major ECM component characterizing advanced fibrosis/cirrhosis [53]. It is very likely that these beneficial actions are largely conducted by specifically differentiated monocyte-derived cells, because the adoptive transfer of macrophage subsets into (regressing) experimental fibrosis was shown to improve hepatic fibrosis in mice [54]. Similarly, distinct subpopulations of myeloid (likely monocyte-derived) dendritic cells have been observed during fibrosis regression, which also functionally facilitated hepatic fibrosis regression upon adoptive transfer experiments in mice [55]. However, the exact phenotype of infiltrating monocytes and monocyte-derived cells during fibrosis regression and its potential for cellbased therapeutic approaches in humans demands further investigations.

\section{Translation of findings from murine models into human pathogenesis}

The recent advances in understanding the role of monocyte subsets and macrophage actions in murine experimental hepatic fibrosis raised the question whether these mechanisms can be directly translated into human pathogenesis. CCL2-CCR2 interactions had long been suggested as an important mediator of macrophage accumulation in human liver diseases as well [56]. As the interference with monocyte subset infiltration, differentiation and activation may represent an interesting novel target for future therapeutic approaches in liver fibrosis [1], our laboratory aimed at defining the functional contributions of monocyte subpopulations to liver fibrogenesis in human liver disease as well. We therefore analyzed circulating monocyte subsets from freshly drawn blood samples of 226 patients with chronic liver disease (CLD) and 184 healthy controls by FACS analysis [57]. Circulating monocytes were significantly expanded in CLD-patients compared to controls with a marked increase of the 'non-classical' $\mathrm{CD} 14^{+} \mathrm{CD} 16^{+}$subset. These $\mathrm{CD} 14^{+} \mathrm{CD} 16^{+}$monocytes showed an activated phenotype in patients (e.g., increased HLA-DR expression) and correlated with proinflammatory cytokines and clinical progression. Correspondingly, $\mathrm{CD} 14^{+} \mathrm{CD} 16^{+}$macrophages massively accumulated in fibrotic/cirrhotic livers, as evidenced by immune-fluorescence and FACS from biopsies and explanted cirrhotic livers. Ligands of monocyterelated chemokine receptors CCR2, CCR1 and CCR5 were expressed at higher levels in fibrotic and cirrhotic livers, while CCL3 and CCL4 were also systemically elevated in CLD-patients [57]. Fractalkine was significantly up-regulated in the circulation upon disease progression, while $\mathrm{CX}_{3} \mathrm{CR} 1$ was down-regulated intrahepatically in patients with advanced liver fibrosis or cirrhosis [48]. However, it has to be kept in mind that despite many similarities the chemokine system between mice and men do not fully overlap. As such, interleukin-8 (IL-8, CXCL8), a potent chemoattractant for neutrophils and ligand for the receptors CXCR1 and CXCR2, has no direct homologue in mice. IL-8 is strongly upregulated in the livers and the serum of patients with liver fibrosis [58]. Interestingly, IL-8 does not seem to primarily promote neutrophil attraction during fibrogenesis, but rather contributes to accumulation of monocytes in fibrotic livers, as circulating monocytes in patients with cirrhosis significantly upregulate CXCR1 on their surface [58].

We also isolated human monocyte/macrophage subpopulations from healthy volunteers and patients with liver cirrhosis to functionally characterize these subsets regarding cytokine/chemokine expression and interactions with primary human hepatic stellate cells (HSC) in vitro. $\mathrm{CD} 14^{+} \mathrm{CD} 16^{+}$monocytes released abundant proinflammatory cytokines. Furthermore, $\mathrm{CD} 14^{+} \mathrm{CD} 16^{+}$, but not $\mathrm{CD} 14^{+} \mathrm{CD} 16^{-}$monocytes could directly activate collagen-producing HSC [57].

Given the assumption that $\mathrm{CD} 14^{+} \mathrm{CD} 16^{+}$monocytes would resemble Ly6C $\mathrm{C}^{\text {lo }}$ cells in mice [13], our findings 
reveal a considerable discrepancy in human disease from mouse models, because fibrosis induction and progression in mice is accompanied by Ly6 $\mathrm{C}^{\mathrm{hi}}$ monocytosis in peripheral blood and infiltration of Ly6 $\mathrm{C}^{\text {hi }}$ monocytes into the injured liver [4]. The reasons for this discrepancy are currently unknown. One obvious difference between murine models and the human diseased liver is the strikingly dissimilar time-course of fibrosis development. Whereas experimental murine fibrosis is analyzed at three or six weeks after induction, e.g. by BDL or $\mathrm{CCl}_{4}$ injection, human fibrosis and cirrhosis usually develops over decades of chronic injury and inflammation, and the most prominent enrichment of $\mathrm{CD} 14^{+} \mathrm{CD} 16^{+}$monocytes were apparent in end-stage cirrhosis [57]. On the other hand, the assumption that $\mathrm{CD} 14^{+} \mathrm{CD} 16^{+}$human monocytes are equivalents of murine $\mathrm{Ly}^{6} \mathrm{C}^{\mathrm{lo}}$ monocytes is primarily based on conserved gene and protein profiles between these subsets [16], but not on functional assays. In more functional approaches, only CD14-low expressing $\mathrm{CD}_{16}{ }^{+}$monocytes (so called $\mathrm{CD} 14^{\text {dim }}$ cells) displayed characteristics of murine Ly6 $\mathrm{C}^{\mathrm{lo}}$ monocytes [19]. Our experiments demonstrated that murine Ly6C ${ }^{\text {hi }}$ monocyte-derived cells in inflammatory conditions and human $\mathrm{CD} 14^{+} \mathrm{CD} 16^{+}$-derived macrophages share important functional properties, particularly the expression of pro-inflammatory cytokines such as TNF $\alpha$ or nitric oxide, and the ability to directly activate HSC $[4,57]$.

With respect to human hepatofibrogenesis, our data demonstrate the expansion of $\mathrm{CD} 14^{+} \mathrm{CD} 16^{+}$monocytes in the circulation and liver of CLD-patients upon disease progression and suggest their functional contribution to the perpetuation of intrahepatic inflammation and profibrogenic HSC activation in liver cirrhosis. The modulation of monocyte-subset recruitment into the liver via chemokines/chemokine receptors and their subsequent differentiation may therefore indeed represent promising approaches for therapeutic interventions in human liver fibrosis [51].

\section{Conclusions}

Monocytes are circulating cellular precursors for macrophages and dendritic cells. In mice and men, monocyte subpopulations have been identified that differ with respect to migratory and functional behaviour. Accumulating experimental evidence recently emphasized that the infiltration of inflammatory monocyte subsets is a key factor for the progression of hepatic inflammation and fibrosis in injured murine liver. CCR2 and $\mathrm{CX}_{3} \mathrm{CR} 1$ have been identified as critical, partially counteracting chemokine pathways regulating monocyte migration and differentiation in hepatofibrogenesis. In patients with chronic liver diseases and cirrhosis, non-classical $\mathrm{CD} 14^{+} \mathrm{CD} 16^{+}$monocytes exert pro-inflammatory and pro-fibrogenic actions. The therapeutic targeting of monocyte/macrophages by interfering with their migration (chemokine inhibitors) and differentiation or by direct cell transplantation during progression and regression of fibrosis are currently under intense investigation.

\section{List of abbreviations}

BDL: bile duct ligation; BM: bone marrow; CCR: C-C motif chemokine receptor; $\mathrm{CCL}$ : $\mathrm{C}-\mathrm{C}$ - motif chemokine; $\mathrm{CCl}_{4}$ : carbon tetrachloride; $\mathrm{CX}_{3} \mathrm{CL} 1$ : fractalkine; $C X_{3} C R 1$ : fractalkine receptor; FACS: fluorescence activated cell sorting; Gr1: myeloid cell marker; HBV: hepatitis B virus; HCV: hepatitis C virus; HSC: hepatic stellate cell; IL: interleukin; Ly6C: myeloid cell marker; MCP-1: monocyte chemoattractant protein-1; SMA: smooth muscle actin; TGF $\beta$ : transforming growth factor beta; TNF: tumor necrosis factor.

\section{Acknowledgements}

This article has been published as part of Fibrogenesis \& Tissue Repair Volume 5 Supplement 1, 2012: Proceedings of Fibroproliferative disorders: from biochemical analysis to targeted therapies. The full contents of the supplement are available online at http://www.fibrogenesis.com/ supplements/5/S1.

I cordially thank all members of my lab and collaborating scientists at the Department of Medicine III for helpful discussions. This work was supported by the German Research Foundation (DFG-Ta434/2-1, SFB-TRR57). This review intends to mainly discuss findings from my laboratory as a summary report from the international conference "Fibroproliferative Disorders: From biochemical analysis to targeted therapies". I therefore sincerely apologize to all experts in this field, whose work could not be presented in detail.

\section{Competing interests}

The laboratory of Frank Tacke has received funding in the past from Noxxon Pharma GmbH, Berlin, Germany.

Published: 6 June 2012

\section{References}

1. Heymann F, Trautwein C, Tacke F: Monocytes and macrophages as cellular targets in liver fibrosis. Inflamm Allergy Drug Targets 2009, 8:307-318.

2. Bataller R, Brenner DA: Liver fibrosis. J Clin Invest 2005, 115:209-218.

3. Imamura M, Ogawa T, Sasaguri Y, Chayama K, Ueno H: Suppression of macrophage infiltration inhibits activation of hepatic stellate cells and liver fibrogenesis in rats. Gastroenterology 2005, 128:138-146.

4. Karlmark KR, Weiskirchen R, Zimmermann HW, Gassler N, Ginhoux F, Weber C, Merad M, Luedde T, Trautwein C, Tacke F: Hepatic recruitment of the inflammatory Gr1+ monocyte subset upon liver injury promotes hepatic fibrosis. Hepatology 2009, 50:261-274.

5. Mitchell C, Couton D, Couty JP, Anson M, Crain AM, Bizet V, Renia L, Pol S, Mallet V, Gilgenkrantz H: Dual role of CCR2 in the constitution and the resolution of liver fibrosis in mice. Am J Pathol 2009, 174:1766-1775.

6. Seki E, de Minicis S, Inokuchi S, Taura K, Miyai K, van Rooijen N, Schwabe RF, Brenner DA: CCR2 promotes hepatic fibrosis in mice. Hepatology 2009, 50:185-197.

7. Duffield JS, Forbes SJ, Constandinou CM, Clay S, Partolina M, Vuthoori S, Wu S, Lang R, Iredale JP: Selective depletion of macrophages reveals distinct, opposing roles during liver injury and repair. J Clin Invest 2005, 115:56-65.

8. Klein I, Cornejo JC, Polakos NK, John B, Wuensch SA, Topham DJ, Pierce RH, Crispe IN: Kupffer cell heterogeneity: functional properties of bone marrow derived and sessile hepatic macrophages. Blood 2007, 110:4077-4085.

9. Seki E, De Minicis S, Gwak GY, Kluwe J, Inokuchi S, Bursill CA, Llovet JM, Brenner DA, Schwabe RF: CCR1 and CCR5 promote hepatic fibrosis in mice. J Clin Invest 2009, 119:1858-1870.

10. Jenkins SJ, Ruckerl D, Cook PC, Jones LH, Finkelman FD, van Rooijen N, MacDonald AS, Allen JE: Local macrophage proliferation, rather than recruitment from the blood, is a signature of $\mathrm{TH} 2$ inflammation. Science 2011, 332:1284-1288.

11. Tacke F, Kurts C: Infiltrating monocytes versus resident Kupffer cells: do alternatively activated macrophages need to be targeted alternatively? Hepatology 2011, 54:2267-2270. 
12. Geissmann F, Manz MG, Jung S, Sieweke MH, Merad M, Ley K: Development of monocytes, macrophages, and dendritic cells. Science 2010, 327:656-661.

13. Tacke F, Randolph GJ: Migratory fate and differentiation of blood monocyte subsets. Immunobiology 2006, 211:609-618.

14. Passlick B, Flieger D, Ziegler-Heitbrock HW: Identification and characterization of a novel monocyte subpopulation in human peripheral blood. Blood 1989, 74:2527-2534.

15. Seidler S, Zimmermann HW, Bartneck M, Trautwein C, Tacke F: Agedependent alterations of monocyte subsets and monocyte-related chemokine pathways in healthy adults. BMC Immunol 2010, 11:30.

16. Ingersoll MA, Spanbroek R, Lottaz C, Gautier EL, Frankenberger M, Hoffmann R, Lang R, Haniffa M, Collin M, Tacke F, et al: Comparison of gene expression profiles between human and mouse monocyte subsets. Blood 2010, 115:e10-19.

17. Geissmann F, Jung S, Littman DR: Blood monocytes consist of two principal subsets with distinct migratory properties. Immunity 2003, 19:71-82.

18. Wong KL, Tai JJ, Wong WC, Han H, Sem X, Yeap WH, Kourilsky P, Wong SC: Gene expression profiling reveals the defining features of the classical, intermediate, and nonclassical human monocyte subsets. Blood 2011, 118:e16-31.

19. Cros J, Cagnard N, Woollard K, Patey N, Zhang SY, Senechal B, Puel A, Biswas SK, Moshous D, Picard C, et al: Human CD14dim monocytes patrol and sense nucleic acids and viruses via TLR7 and TLR8 receptors. Immunity 2010, 33:375-386.

20. Tacke F, Alvarez D, Kaplan TJ, Jakubzick C, Spanbroek R, Llodra J, Garin A, Liu J, Mack M, van Rooijen N, et al: Monocyte subsets differentially employ CCR2, CCR5, and CX3CR1 to accumulate within atherosclerotic plaques. J Clin Invest 2007, 117:185-194.

21. Le Borgne M, Etchart N, Goubier A, Lira SA, Sirard JC, van Rooijen N, Caux C, Ait-Yahia S, Vicari A, Kaiserlian D, Dubois B: Dendritic cells rapidly recruited into epithelial tissues via CCR6/CCL20 are responsible for CD8+ T cell crosspriming in vivo. Immunity 2006, 24:191-201.

22. Tsou CL, Peters W, Si Y, Slaymaker S, Aslanian AM, Weisberg SP, Mack M, Charo IF: Critical roles for CCR2 and MCP-3 in monocyte mobilization from bone marrow and recruitment to inflammatory sites. J Clin Invest 2007, 117:902-909.

23. Vanbervliet B, Homey B, Durand I, Massacrier C, Ait-Yahia S, de Bouteiller O, Vicari A, Caux C: Sequential involvement of CCR2 and CCR6 ligands for immature dendritic cell recruitment: possible role at inflamed epithelial surfaces. Eur J Immunol 2002, 32:231-242.

24. Engel DR, Maurer J, Tittel AP, Weisheit C, Cavlar T, Schumak B, Limmer A, van Rooijen N, Trautwein C, Tacke F, Kurts C: CCR2 mediates homeostatic and inflammatory release of $\mathrm{Gr} 1$ (high) monocytes from the bone marrow, but is dispensable for bladder infiltration in bacterial urinary tract infection. J Immunol 2008, 181:5579-5586.

25. Serbina NV, Kuziel W, Flavell R, Akira S, Rollins B, Pamer EG: Sequentia MyD88-independent and -dependent activation of innate immune responses to intracellular bacterial infection. Immunity 2003, 19:891-901.

26. Serbina NV, Pamer EG: Monocyte emigration from bone marrow during bacterial infection requires signals mediated by chemokine receptor CCR2. Nat Immunol 2006, 7:311-317.

27. Osterholzer Jل J Ames T, Polak T, Sonstein J, Moore BB, Chensue SW, Toews GB, Curtis JL: CCR2 and CCR6, but not endothelial selectins, mediate the accumulation of immature dendritic cells within the lungs of mice in response to particulate antigen. J Immunol 2005, 175:874-883.

28. Robays LJ, Maes T, Lebecque S, Lira SA, Kuziel WA, Brusselle GG, Joos GF, Vermaelen KV: Chemokine receptor CCR2 but not CCR5 or CCR6 mediates the increase in pulmonary dendritic cells during allergic airway inflammation. J Immunol 2007, 178:5305-5311.

29. Heymann F, Hammerich L, Storch D, Bartneck M, Huss S, Russeler V, Gassler N, Lira SA, Luedde T, Trautwein C, Tacke F: Hepatic macrophage migration and differentiation critical for liver fibrosis is mediated by the chemokine receptor $\mathrm{C}-\mathrm{C}$ motif chemokine receptor 8 in mice. Hepatology 2012, 55(3):898-909.

30. Auffray C, Sieweke MH, Geissmann F: Blood monocytes: development, heterogeneity, and relationship with dendritic cells. Annu Rev Immunol 2009, 27:669-692.

31. Bosschaerts T, Guilliams M, Stijlemans B, Morias Y, Engel D, Tacke F, Herin M, De Baetselier P, Beschin A: Tip-DC development during parasitic infection is regulated by IL-10 and requires CCL2/CCR2, IFN-gamma and MyD88 signaling. PLoS Pathog 2010, 6:e1001045.

32. Auffray C, Fogg D, Garfa M, Elain G, Join-Lambert O, Kayal S, Sarnacki S, Cumano A, Lauvau G, Geissmann F: Monitoring of blood vessels and tissues by a population of monocytes with patrolling behavior. Science 2007, 317:666-670

33. Nahrendorf $M$, Swirski FK, Aikawa E, Stangenberg L, Wurdinger $T$, Figueiredo JL, Libby P, Weissleder R, Pittet MJ: The healing myocardium sequentially mobilizes two monocyte subsets with divergent and complementary functions. J Exp Med 2007, 204:3037-3047

34. Swirski FK, Nahrendorf M, Etzrodt M, Wildgruber M, Cortez-Retamozo V, Panizzi P, Figueiredo $\mathrm{L}$, Kohler RH, Chudnovskiy A, Waterman P, et al: Identification of splenic reservoir monocytes and their deployment to inflammatory sites. Science 2009, 325:612-616.

35. Tacke F, Ginhoux F, Jakubzick C, van Rooijen N, Merad M, Randolph GJ: Immature monocytes acquire antigens from other cells in the bone marrow and present them to T cells after maturing in the periphery. J Exp Med 2006, 203:583-597.

36. Varol C, Landsman L, Fogg DK, Greenshtein L, Gildor B, Margalit R, Kalchenko V, Geissmann F, Jung S: Monocytes give rise to mucosal, but not splenic, conventional dendritic cells. J Exp Med 2007, 204:171-180.

37. Hanna RN, Carlin LM, Hubbeling HG, Nackiewicz D, Green AM, Punt JA, Geissmann F, Hedrick CC: The transcription factor NR4A1 (Nur77) controls bone marrow differentiation and the survival of Ly6C-monocytes. Nat Immunol 2011, 12:778-785.

38. Tacke F, Kurts C: Infiltrating monocytes versus resident Kupffer cells - do alternatively activated macrophages need to be targeted alternatively? Hepatology 2011, 54(6):2267-2270

39. Seki E, De Minicis S, Osterreicher CH, Kluwe J, Osawa Y, Brenner DA Schwabe RF: TLR4 enhances TGF-beta signaling and hepatic fibrosis. Nat Med 2007, 13:1324-1332.

40. Tacke F, Weiskirchen R: Update on hepatic stellate cells: pathogenic role in liver fibrosis and novel isolation techniques. Expert Rev Gastroenterol Hepatol 2012, 6:67-80.

41. Baeck C, Wehr A, Karlmark KR, Heymann F, Vucur M, Gassler N, Huss S, Klussmann S, Eulberg D, Luedde T, et al: Pharmacological inhibition of the chemokine CCL2 (MCP-1) diminishes liver macrophage infiltration and steatohepatitis in chronic hepatic injury. Gut 2012, 61:416-426.

42. Efsen E, Grappone C, DeFranco RM, Milani S, Romanelli RG, Bonacchi A, Caligiuri A, Failli P, Annunziato F, Pagliai G, et al: Up-regulated expression of fractalkine and its receptor CX3CR1 during liver injury in humans. $J$ Hepatol 2002, 37:39-47

43. Isse K, Harada K, Zen Y, Kamihira T, Shimoda S, Harada M, Nakanuma Y: Fractalkine and CX3CR1 are involved in the recruitment of intraepithelial lymphocytes of intrahepatic bile ducts. Hepatology 2005, 41:506-516.

44. Shimoda S, Harada K, Niiro H, Taketomi A, Maehara Y, Tsuneyama K, Kikuchi K, Nakanuma Y, Mackay IR, Gershwin ME, Akashi K: CX3CL1 (fractalkine): a signpost for biliary inflammation in primary biliary cirrhosis. Hepatology 2010, 51:567-575.

45. Wasmuth HE, Zaldivar MM, Berres ML, Werth A, Scholten D, Hillebrandt S, Tacke F, Schmitz P, Dahl E, Wiederholt T, et al: The fractalkine receptor CX3CR1 is involved in liver fibrosis due to chronic hepatitis $C$ infection. $J$ Hepatol 2008, 48:208-215.

46. Bourd-Boittin K, Basset L, Bonnier D, L'Helgoualch A, Samson M, Theret $N$ : CX3CL1/fractalkine shedding by human hepatic stellate cells: contribution to chronic inflammation in the liver. J Cell Mol Med 2009, 13:1526-1535.

47. Aspinall Al, Curbishley SM, Lalor PF, Weston CJ, Blahova M, Liaskou E, Adams RM, Holt AP, Adams DH: CX3CR1 and VAP-1 dependent recruitment of $\mathrm{CD} 16+$ monocytes across human liver sinusoidal endothelium. Hepatology 2010, 51:2030-2039.

48. Karlmark KR, Zimmermann HW, Roderburg C, Gassler N, Wasmuth HE, Luedde T, Trautwein C, Tacke F: The fractalkine receptor CX3CR1 protects from liver fibrosis by controlling differentiation and survival of infiltrating hepatic monocytes. Hepatology 2010, 52(5):1769-1782.

49. Aoyama T, Inokuchi S, Brenner DA, Seki E: CX3CL1-CX3CR1 interaction prevents carbon tetrachloride-induced liver inflammation and fibrosis in mice. Hepatology 2010, 52:1390-1400.

50. Imai T, Hieshima K, Haskell C, Baba M, Nagira M, Nishimura M, Kakizaki M, Takagi S, Nomiyama H, Schall TJ, Yoshie O: Identification and molecular 
characterization of fractalkine receptor CX3CR1, which mediates both leukocyte migration and adhesion. Cell 1997, 91:521-530.

51. Zimmermann HW, Tacke F: Modification of chemokine pathways and immune cell infiltration as a novel therapeutic approach in liver inflammation and fibrosis. Inflamm Allergy Drug Targets 2011, 10:509-536.

52. Fallowfield JA, Mizuno M, Kendall TJ, Constandinou CM, Benyon RC, Duffield JS, Iredale JP: Scar-associated macrophages are a major source of hepatic matrix metalloproteinase-13 and facilitate the resolution of murine hepatic fibrosis. J Immunol 2007, 178:5288-5295.

53. Pellicoro A, Aucott RL, Ramachandran P, Robson AJ, Fallowfield JA, Snowdon VK, Hartland SN, Vernon M, Duffield JS, Benyon RC, et al: Elastin accumulation is regulated at the level of degradation by macrophage metalloelastase (MMP-12) during experimental liver fibrosis. Hepatology 2011.

54. Thomas JA, Pope C, Wojtacha D, Robson AJ, Gordon-Walker TT, Hartland S, Ramachandran P, Van Deemter M, Hume DA, Iredale JP, Forbes SJ: Macrophage therapy for murine liver fibrosis recruits host effector cells improving fibrosis, regeneration, and function. Hepatology 2011, 53:2003-2015.

55. Jiao J, Sastre D, Fiel MI, Lee UE, Ghiassi-Nejad Z, Ginhoux F, Vivier E, Friedman SL, Merad M, Aloman C: Dendritic cell regulation of carbon tetrachloride-induced murine liver fibrosis regression. Hepatology 2012, 55:244-255.

56. Marra F, DeFranco R, Grappone C, Milani S, Pastacaldi S, Pinzani M, Romanelli RG, Laffi G, Gentilini P: Increased expression of monocyte chemotactic protein-1 during active hepatic fibrogenesis: correlation with monocyte infiltration. Am J Pathol 1998, 152:423-430.

57. Zimmermann HW, Seidler S, Nattermann J, Gassler N, Hellerbrand C, Zernecke A, Tischendorf JJ, Luedde T, Weiskirchen R, Trautwein C, Tacke F: Functional contribution of elevated circulating and hepatic non-classical CD14CD16 monocytes to inflammation and human liver fibrosis. PLoS One 2010, 5:e11049.

58. Zimmermann HW, Seidler S, Gassler N, Nattermann J, Luedde T, Trautwein C, Tacke F: Interleukin-8 is activated in patients with chronic liver diseases and associated with hepatic macrophage accumulation in human liver fibrosis. PLoS One 2011, 6:e21381.

doi:10.1186/1755-1536-5-S1-S27

Cite this article as: Tacke: Functional role of intrahepatic monocyte subsets for the progression of liver inflammation and liver fibrosis in vivo. Fibrogenesis \& Tissue Repair 2012 5(Suppl 1):S27.

\section{Submit your next manuscript to BioMed Central and take full advantage of:}

- Convenient online submission

- Thorough peer review

- No space constraints or color figure charges

- Immediate publication on acceptance

- Inclusion in PubMed, CAS, Scopus and Google Scholar

- Research which is freely available for redistribution 